\title{
Enhanced Satellite Cell Activity in Aging Skeletal Muscle after Manual Acupuncture-Induced Injury
}

\author{
Sonya K. Sobrian ${ }^{1 *}$, Eric Walters ${ }^{2}$ \\ ${ }^{1}$ Department of Pharmacology, Howard University College of Medicine, Washington, USA \\ ${ }^{2}$ Department of Biochemistry and Molecular Biology, Howard University College of Medicine, Washington, USA \\ Email: ssobrian@howard.edu
}

Received 14 December 2013; revised 22 January 2014; accepted 13 February 2014

Copyright (C 2014 by authors and Scientific Research Publishing Inc.

This work is licensed under the Creative Commons Attribution International License (CC BY). http://creativecommons.org/licenses/by/4.0/

(c) (i) Open Access

\begin{abstract}
Skeletal muscle injury stimulates normally quiescent resident satellite (stem) cells to re-enter the cell cycle and execute the myogenic program to restore muscle structure and function. Previously, we reported that manual acupuncture needling of the tibialis anterior (TA) (ST36 = Zusanli) muscle of young male rats produced focal injury and morphological changes that accompanied the presence of activated satellite cells (SC) 72 hours post-needling. To investigate whether aging TA muscle responds in a similar fashion to acupuncture needling, 17-month-old female rats were subjected to a single insertion and manual manipulation of an acupuncture needle. At 72 hours' post-needling, hematoxylin staining of the $T A$ revealed increased mononuclear cell infiltration that was indicative of localized injury. Moreover, this was accompanied by a four-fold increase in the expression of proliferating cell nuclear antigen within cells of needled tissues. Heightened immunofluorescence for MyoD was found within SC in the needled muscle, which correlated with a 6- and 10-fold increase in two MyoD isoforms ( 38 and $42 \mathrm{kDa}$, respectively), when analyzed by Western blotting. An additional $56 \mathrm{kDa}$ MyoD immunoreactive species was observed in both needled and control muscle of the aging rats. The present study in pre-senile female rats, in conjunction with our previous study in young male rats, suggests that muscle remodeling and restructuring after injury may constitute the initial cellular and molecular mechanisms that underlie the benefits associated with acupuncture throughout the life-span.
\end{abstract}

\section{Keywords}

Aging Rat; Manual Acupuncture; Muscle Injury; Regeneration; ST 36 = Zusanli; Stem Cells

\footnotetext{
${ }^{*}$ Corresponding author.
} 


\section{Introduction}

Skeletal muscle contains specialized somatic stem cells that are termed satellite cells (SC) because of their location on the periphery of myofibers under the surrounding basal lamina [1] [2]. These resident satellite cells are responsible for muscle growth and repair after injury throughout the life span [3]. In normal undisturbed muscle, these cells remain in a quiescent stage [4]. After muscle injury, satellite cells become mitotically active. The transcription factor MyoD is essential for promoting gene expression that regulates proliferation, differentiation and the regeneration of new muscle fiber [3]-[6]. The activated phenotype is defined by the presence of MyoD [7].

Satellite cell activation, which is necessary for muscle regeneration, has been analyzed using experimental models that induce injury by crushing [4], or injection of notexin [8] [9]. These methods are, however, invasive and/or prohibited in therapeutic settings, and may produce extensive damage to elements within muscle that are crucial for regeneration [10]. In contrast, muscle injury as a consequence of exercise can also activate satellite cell proliferation in both humans and laboratory animals [11] [12]. There is an increasing acceptance of acupuncture as a treatment modality for a variety of muscle-related illnesses [13], and acupuncture needling has been shown to provide clinically relevant short- and long-term benefits for low back pain, osteoarthritis, rheumatoid arthritis, chronic neck pain, myofacial pain syndrome, and headache [14] [15]. In Chinese medicine, disease is understood as a consequence of an imbalance in energy flow within 12 channels, or meridians, throughout the body [16], and acupuncture needling is thought to restore healthy energy balance [17]. While data from clinical and experimental studies indicated participation of both the central and peripheral nervous systems, and the involvement of psychological and physiological responses [18], the exact mechanism of action for acupuncture's efficacy has not been elucidated. We previously hypothesized that therapeutic potential of acupuncture was linked to regenerative processes that follow muscle injury induced by needle manipulation, and demonstrated that acupuncture needling of the tibialis anterior (TA) muscle in young male rats produced focal muscle damage that was accompanied by the presence of activated satellite cells [19]. In contrast to the regenerative potential seen in young muscle, the general consensus is that with increasing age there is a decline in skeletal muscle's response to injury. Although satellite cells exist in muscle from birth through senescence [20], their repair capacity [21]-[23], the regenerative potential of satellite cells [24]-[26], and aspects of the regenerative response are impaired in aging muscle [27].

This reduced regenerative capacity of aging muscle has been partially attributed to decreases in the number of available satellite cells [28]-[30]. While most studies, especially those in rodent, suggest a gradual decline in SC number with increasing age [28]-[34], there are inconsistencies. Similar numbers of SC have been reported between the young and old in both humans and animals [22] [35]-[38]; in addition, relative increases in SC numbers have also been observed with aging [24] [39].

There is debate with respect to the functional significance of any change in the number of SCs with increasing age [27]. A reduction in SC number in aged muscle does not appear to affect regeneration or repair, provided that a critical minimum population is present [25] [40] [41]. It is hypothesized that the loss of regenerative potential and generalized atrophy of aged skeletal muscle may be a consequence of an age-related loss of satellite cell function [24] [36]. This loss of functionality may reflect alterations in SC-intrinsic properties, such as erosion of telomere sequences and accumulation of DNA damage [29] [41], diminished responsiveness to intrinsic cues in the niché environment [22] [42], or a decreased responsiveness to systemic signals that govern remodeling and regeneration [24] [27] [41] [43]-[46]. Indeed, the proliferative and regenerative capacities of SC in muscle from old mice are restored after exposure to serum from young mice, or transplantation of aging mouse muscle to a young host [21] [34] [39] [47]-[49]. These observations support the hypothesis that in aging muscle a subset of satellite cells maintains myogenic stem cell properties. Therefore, the purpose of the present study was to assess the effect of manual acupuncture needling on aging tibialis anterior (TA) skeletal muscle by: 1) determining if manual needling produced localized injury to the muscle, and 2) assessing if muscle injury correlated with regeneration processes similar to what was previously observed in young adult rats [19].

\section{Material and Methods}

\subsection{Laboratory Animals}

Eight, 17.2 month-old pre-senile female Sprague-Dawley rats (Harlan Sprague-Dawley, Indianapolis, IN), 280 360 grams (mean $=324.08+10.67 \mathrm{~g}$ ) were used for this experiment. Female Sprague-Dawley rats gradually 
cease cycling by 6 - 8 months of age [50] [51], and cease to breed by 15 months of age [52], thus minimizing the influence of estrogen on myogenic satellite cells that has previously been reported [53]-[55]. However, muscle satellite cells from old ( $>30$ months) female rats retain their myogenic potential [56].

Females were housed in groups of 2 in polyethylene shoebox cages $(44 \times 25 \times 30 \mathrm{~cm})$ lined with corncob bedding, under environmentally controlled conditions ( $0700 \mathrm{hr}$ lights on, $1900 \mathrm{hr}$ lights off, ambient temperature $20^{\circ} \mathrm{C}-23^{\circ} \mathrm{C}$, relative humidity $40 \%-60 \%$ ) with ad libitum access to Purina Rat Chow and tap water. All procedures were performed with the approval of the Howard University Institutional Animal Care and Use Committee.

\subsection{Acupuncture and Muscle Sampling}

Rats were lightly anesthetized with sodium pentobarbital (40 mg/kg, i.p.) and a sterile, $0.30 \mathrm{~mm}$ diameter stainless steel acupuncture needle (Seirin Co. Ltd., Germany) was inserted perpendicularly into the shaved right hind leg TA muscle, at a point equivalent to human Zusanli (ST 36). The ST 36 acupoint is located $5 \mathrm{~mm}$ below and anterior to the tubercle of the tibia [57]. The acupuncture needle was inserted to a depth of $2 \mathrm{~mm}$, and manually twisted from left to right for 20 seconds every $3 \mathrm{~min}$, during the 15 minute session, resulting in 5 needle manipulations. The left TA muscle served as the control; the hind leg was shaved but no needle was inserted [58], in order to avoid the reported controversies associated with the placement of sham needles, which produce biological effects that may complicate interpretation of results [59]. ST 36 is the most commonly targeted acupuncture needle point in both clinical settings [60] and experimental studies [58] [61], and is considered to be more effective in restoring energy balance in humans than other points according to traditional acupuncture medical theory [62].

At 72 hours post-acupuncture, rats were sacrificed and portions of the ST 36 area of the TA muscle $(10 \times 5 \times$ $4 \mathrm{~mm}$ ) from both the needled and the contralateral control legs were dissected. Half of the tissue was frozen in liquid nitrogen, and stored at $-70^{\circ} \mathrm{C}$. The remaining half of each sample was placed in Prefer fixative (Anatech, Battle Creek, MI), and infiltrated with paraffin [63].

\subsection{Histology and Immunohistochemistry}

Ten (10) micron paraffin sections of dissected TA muscle were cut and stained with hemotoxylin [64]. Paraffin sections were de-waxed in xylenes, and rehydrated as previously described [63], then treated with sodium citrate buffer (10 mM, pH 6.0) for 30 minutes at $80^{\circ} \mathrm{C}$, and incubated overnight with anti-PCNA antibodies [1:75]. Sections were incubated in biotinylated anti-mouse secondary antibody (Vector Labs), followed by ABC reagent (Vector Labs), and chromogen was developed in 3'3-diaminobenzidine/nickel chloride solution. Fifteen (15) micron cryosections of TA muscle were fixed in $4 \%$ paraformaldehyde, incubated overnight with primary antibodies (anti-BrdU, 1U/mL, Roche), (mouse anti-MyoD, 1:30, Dako) followed by FITC labeled secondary antibodies (Dako). All specimens were photographed using a Nikon ES400 microscope.

\subsection{Cell Counting}

Cell counts were calculated by identifying approximately a 1 square millimeter unit area where labeling was concentrated within the targeted anatomical region. Five to ten sections per animal were analyzed and the average number of counts determined constituted a sample $(\mathrm{n}=1)$.

\subsection{Western Blotting}

Dissected TA muscle was homogenized in cold buffer (19 mM NaCl, $1.5 \mathrm{mM} \mathrm{MgCl}_{2}, 20 \mathrm{mM}$ HEPES (pH 7.4), $1 \mathrm{mM}$ dithiothreitol, $20 \%$ glycerol, and $0.1 \%$ Triton X-100) containing protease inhibitors, sonicated on ice (5 minutes), and centrifuged at $14,000 \mathrm{rpm}$ for 15 minutes at $4^{\circ} \mathrm{C}$. Protein concentrations of supernatants were determined [65]; 40 micrograms of protein was electrophoresed in 12\% NuPage Bis-Tris gels (Invitrogen), and transferred to PVDF membranes. Due to the multiplicity of gene expression induced by injury, the choice of a stable gene normalization was limited. Therefore, Ponceau S staining of the Western blot was consistently employed to confirm equal amounts of sample loading and transfer of protein. Membranes were incubated overnight with anti-MyoD1 5.8A monoclonal antibody (1:400, Dako, Carpinteria, CA), followed by peroxidaseconjugated horse anti-mouse secondary antibody (1:1000, Vector Labs). Chemiluminescent signals were densi- 
tometrically quantified using NIH Scion Image (version 4.0.3.2) software.

\subsection{Statistical Analysis}

All quantitative data are expressed as means $+/-$ standard errors. Cell counts and western blot data were analyzed using the paired Student's $t$ test to determine significant differences $(\mathrm{p}<0.05)$.

\section{Results}

\subsection{Acupuncture Induces Injury in TA Muscle}

Histological signs of injury in TA muscle were assessed by hematoxylin staining. Control TA muscle (Figure 1(A)) exhibited a uniform pattern of myofibrils with punctate nuclei. In contrast, acupuncture needling of the TA muscle (Figure 1(B)) resulted in a loss of myofibril integrity and accumulation of mononucleated cells.

\subsection{Acupuncture Induces a Proliferative Response in TA Muscle}

Proliferative activity in response to acupuncture needling was analyzed by quantifying proliferating cell nuclear antigen (PCNA) expression in TA muscles. Compared to control muscle (Figure 2(A)), there was a dramatic increase in the number of proliferating cells in needled TA muscle that was consistent with injury and myofiber disruption (Figure 2(B)). Quantitation of PCNA in serial sections demonstrated a significant $[\mathrm{t}(6)=4.89, \mathrm{p}<$ $0.0001]$ 4-fold elevation in needled tissue [194.00 $\left.\pm 5.12 \mathrm{cells} / \mathrm{mm}^{2}\right]$ compared to controls [50.55 +11.88 cells/ $\mathrm{mm}^{2}$ (Figure 2(C)). Within the injured tissue, discrete sites of proliferative activity were adjacent to intact fibers that lacked immunoreactivity for PNCA (see Figure 2(B)).

\subsection{Acupuncture Promotes Myogenic Potential}

The sequence of myogenesis in response to injury is well characterized. Specifically, activated satellite cells that undergo differentiation are known to express the myogenic transcription factor, MyoD [7]. MyoD is a transcription factor that is the switch for the cascade of genes associated with remodeling a repair of muscle tissue.

Figure 3(B) demonstrates that acupuncture needling prompted MyoD immunoreactivity, in contrast to little or no expression within controls [Figure 3(A)]. Immunoblot analysis showed that there was a 6 and 10 fold increase in two MyoD immunoreactive isoforms (38 and $42 \mathrm{kDa}$, respectively) at 72 hrs after needling (Figure 4), which correlated with results from the in situ profile of MyoD expression (Figure 3). While the increase in the 38 and $42 \mathrm{kDa}$ species reflects normal MyoD in response to muscle injury, another ( 56 kDa) MyoD-immuno-
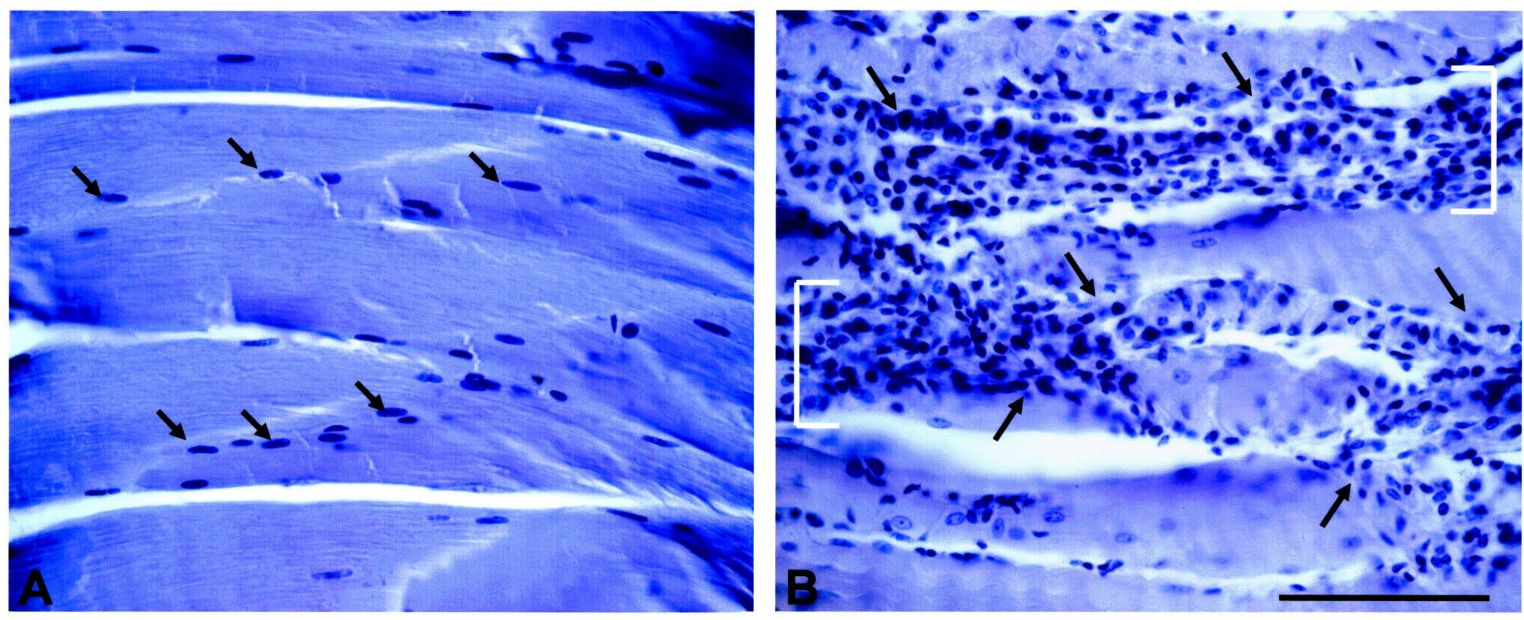

Figure 1. Acupuncture needling-induced signs of TA muscle injury. ((A): Left) Hematoxylin staining of sagittal sections of control TA muscle reveals uniform labeling of compact myofibers and resident nuclei (arrows). ((B): Right) Acupuncture disturbs myofiber integrity of TA muscle, and induces myonecrosis [brackets] and infiltration of mononucleated cells (arrows). Bar $=100 \mu \mathrm{m}$. 

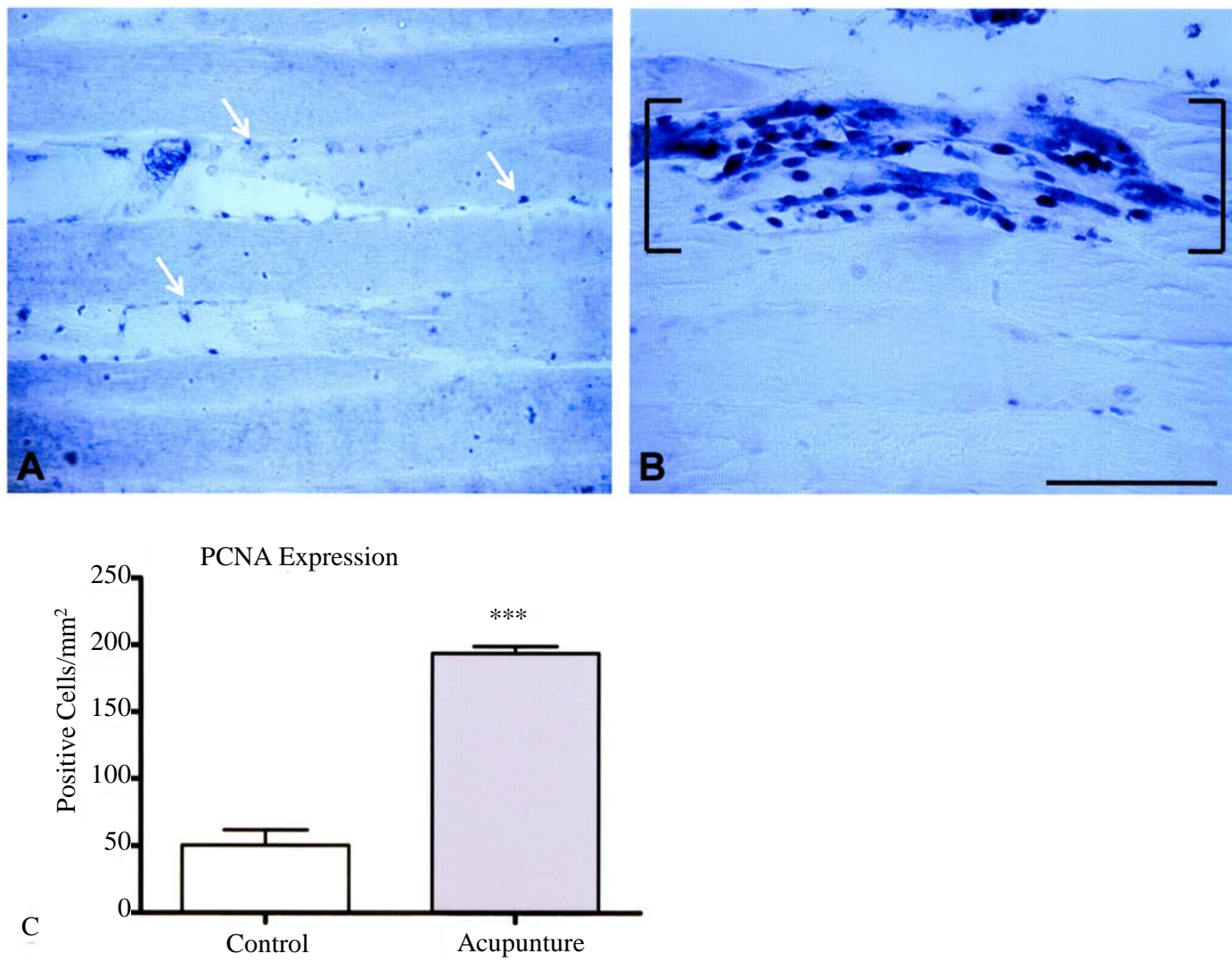

TA Musle

Figure 2. Quantification of proliferation in TA muscle. Sagittal sections of control (A) TA muscle tissue show proliferating cell nuclear antigen (PCNA) expression was limited to superficial regions of the muscle fibers (arrows). (B) Acupunture produced a dramatic accumulation of PCNA-immunoreactive nuclei [brackets] within myofibers $(B a r=100 \mu \mathrm{m})$ that resulted in a significant difference from control TA muscle (see histogram in (C)). Data represent means + s.e.m., $n=4$ /group, ${ }^{* * *} \mathrm{p}<0.0001$.
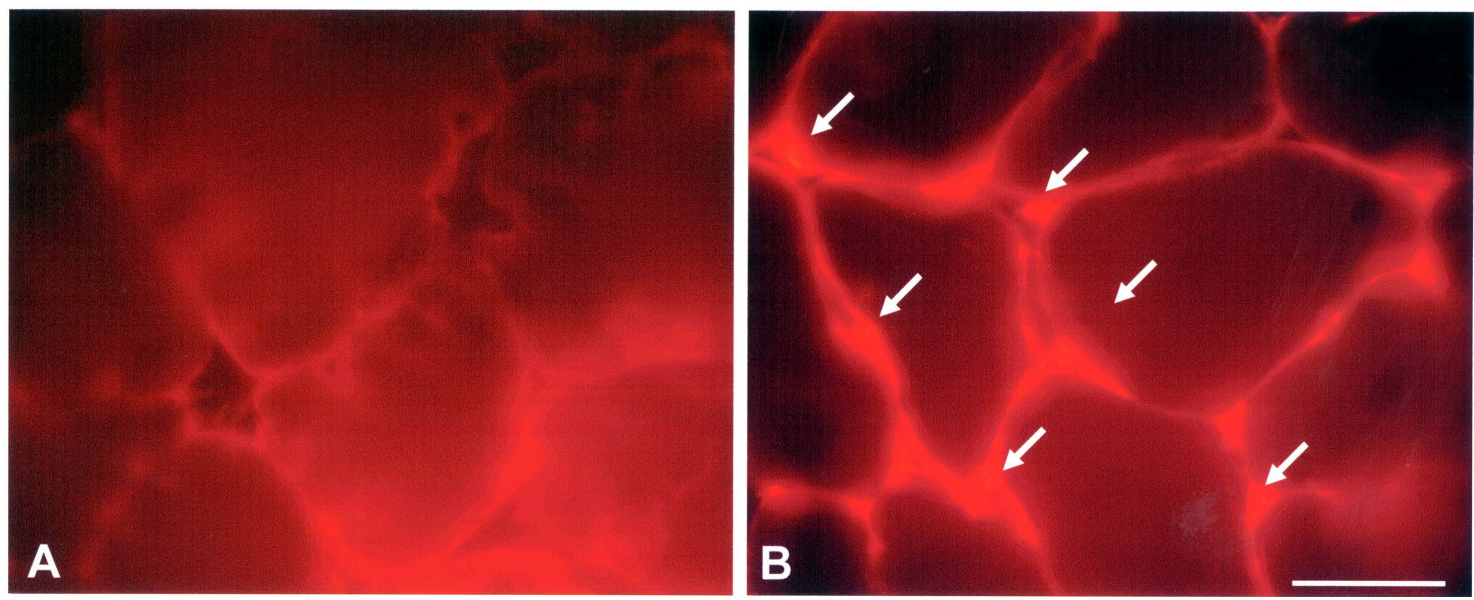

Figure 3. Evidence of myogenic activation in TA muscle. (A) Serial sections of control TA muscle incubated with anti-MyoD antibodies routinely lacked immunoreactivity. (B) Acupunctured TA muscle revealed dense, MyoDpositive immunoreactive profiles within cells at the peripheral membrane of myofibers (arrows). Bar $=50 \mu \mathrm{m}$.

reactive species was expressed in two thirds of the controls, and in one third of experimental of the needled TA muscles (Figure 4(A)). 


\section{A}

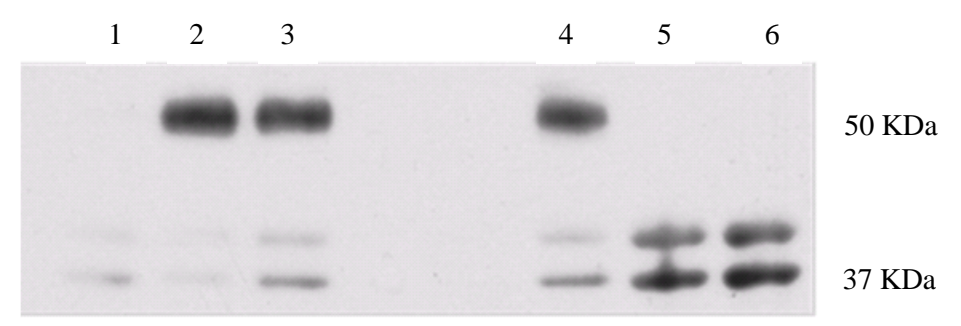

B

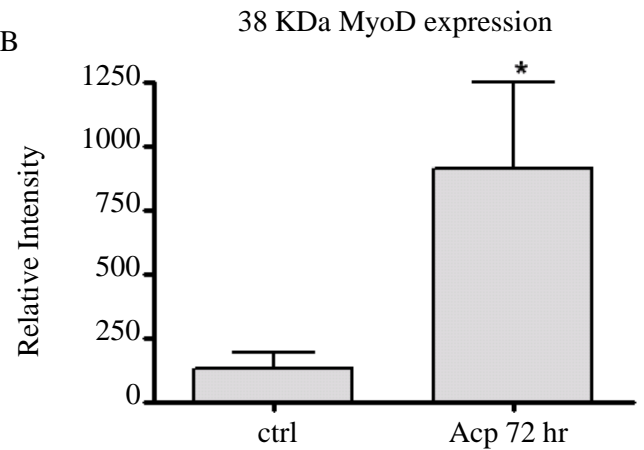

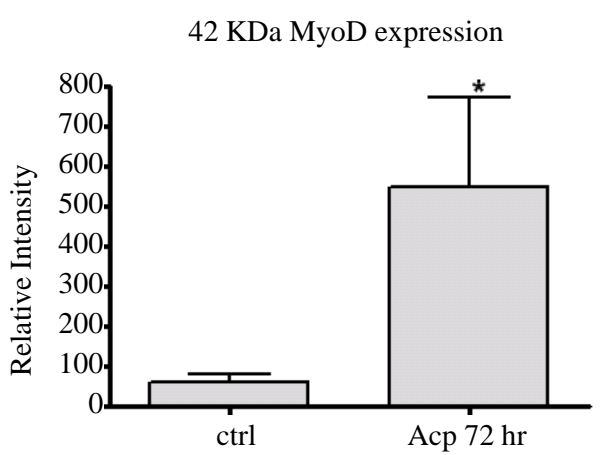

Figure 4. Induction of MyoD expression in TA muscle. Representative Western blot (A) and histograms (B) showing relative levels (mean + s.e.m.) of MyoD-immunoreactivity/expression in control TA muscles (lanes 1 - 3) and acupunctured TA muscles (lanes 4 - 6). MyoD isoforms at $\sim 38$ and 42 $\mathrm{kD}$ were significantly induced in acupunctured TA muscles. A MyoD-immunoreactive species of approximately $56 \mathrm{kDa}$ (see (A)) was also present within the TA muscles of control and acupunctured samples. Asterisks $\left(^{*}\right)$ note significant differences between controls and experimental group means $[\mathrm{t}(5)=3.27, \mathrm{p}<0.05]$. Densitometric scans of Ponceau S stained membranes were used to confirmed equivalent protein amounts from control and acupuncture tissues (not shown).

\section{Discussion}

The present study demonstrates that in the 17-month-old female rat, the TA muscle retains the capacity to express markers that are known to be indicative of mechanisms that promote repair and myogenesis in injured muscle. Acupuncture needling of the TA caused myofibril disorganization that was accompanied by the infiltration of mononucleated cells, increased proliferative activity, and the up-regulation of MyoD transcription factor in SC within 72-hours post-needling. These findings correlate with observations previously reported in 6 week old male rats [19] [66], and are consistent with the results obtained with the use of different muscle injury protocols that promote SC proliferation in young organisms [2] [4] [6] [9] [67] [68].

There are reports, however, of age-related declines in SC-mediated myogenesis in response to acute injury [24] [69] [70]. Myogenic cells from aged muscle show a delayed response to activation cues and an initially reduced proliferative expansion in vitro [22] [45]. Despite these shortcomings, there are sufficient populations of SC that retain the myogenic potential for tissue repair [42], which have been shown to be delayed but excellent in old mice [30].

At 72 hrs post-needling, the TA muscle of rats in the present study displayed evidence of myofiber necrosis and mononuclear cell infiltration indicative of muscle injury. The presence of mononuclear cells is considered critical to the process of phagocytosis and clearance of injured muscle debris [71], which is concomitant with induction of the regeneration process [6]. Characteristic features of central nuclei and reorganizing structures have also been reported at similar time points after injury to skeletal muscle, leading to repair and regeneration [72]. Moreover, injury to mouse TA muscle by contractile lengthening results in several fold increase in the number of necrotic fibers concomitant with significant mononuclear infiltration after days [73].

In the present study, increased PCNA expression was localized within the injured TA muscle. PCNA has been used a as prerequisite marker for muscle regeneration and repair, and proliferation of a SC pool [68] [74] [75]. It is important to note that PCNA plays an essential role assisting DNA polymerase $\delta$ in processes that involve both DNA replication and repair [76]. Thus, the heightened expression of PCNA within the injured TA muscle in rats in this study may reflect induction of the SC activation/entry into the cell cycle process and/or DNA re- 
pair of myofibers. Determination of specific proliferative and immunochemical profiles at earlier post-needling time points within the injured TA muscle will enable further better characterization of myonuclear phenotypes. Preliminary observations of injured TA muscle revealed increased BrdU staining (data not shown).

At cellular and molecular levels, activation of satellite cells in muscle correlates with MyoD expression [40]. MyoD up-regulation during satellite cell activation is documented in response to episodes of myogenic plasticity, adaptation, and regeneration [11] [12] [77]. In proliferating myoblasts, MyoD expression may be critical for their fusion with intact myofibers in response to stimuli produced during muscle injury [78] [79]. In rat skeletal muscle, the molecular weight of MyoD has been reported to range between 33 to $48 \mathrm{kDa}$ [80]. In the current study, two MyoD protein species, at 38- and $42 \mathrm{kDa}$, were significantly elevated in response to acupuncture needling. In a study with male adolescent rats, acupuncture needling induced the expression of the $38 \mathrm{kDa}$ species [66]. However, their reported approximate 4-fold induction of this $38 \mathrm{kDa}$ species differs from the $6-10$ fold induction of this protein in aging female rats, and suggests that age- and sex-specific factors may play significant roles to regulate the myogenic response to acupuncture needling.

Recent studies have uncovered the critical impact of systemic and niché factors on stem cell functionality [46]. Selective estrogen receptor- $\beta$ signaling regulates skeletal muscle regeneration by activating satellite cells and modulating immune responses [68] [81]. Estrogen stimulates skeletal muscle repair and regeneration after trauma [55] [68], and mitigates muscle damage by limiting the inflammatory response [53] [54]. In rodents, sex-related differences in SC number have been reported with aging. The decline in the number of SC in the soleus and extensor digitorium longus muscles with aging has been shown to be more striking in female mice and rats than in their aging male counterparts [82]. However, muscle SC from 30 month old female Long-Evans rats differentiated in culture to form multinucleated myotubules that have the ability to accumulate muscle-specific proteins [56]. Clinically, women have been shown to exhibit faster recovery from exercise-induced muscle damage than men [83]. Although estrogen was not measured in the present experiment, it is likely that in 17month old pre-senile female rats estrogen levels are lower than in adult females of the species [52], suggesting that alternative systemic factors may influence regeneration seen after acupuncture needling in the aging female. It is possible that age and/or sex may account for the expression of the additional MyoD immunoreactive species which was not observed in young males after a similar acupuncture procedure [66].

The expression of a $56 \mathrm{kDa}$ MyoD-immunoreactive species described here in control and needled TA muscle samples of 17 month-old rats has not been previously reported. However, 55 - $65 \mathrm{kDa}$ MyoD proteins have been reported in both adult and senile rats [84]. In 4-month old male rats, these proteins are expressed in control extensor digitorum longus (EDL), gastrocnemius, and TA muscles, and elevated in response to denervation and injury [84]. In senile male rats, they are expressed in uninjured EDL and gastrocnemius muscle, and between 24 32 months of age their expression is steadily enhanced, with total levels in these two muscles showing increases approximately 3 to 11 times higher than at 4 months of age [84]. These high molecular weight MyoD-like species may serve age-related functions that are linked to the homeostatic and regenerative properties of muscle [42].

The $56 \mathrm{kDa}$ species observed in our study may reflect the addition of ubiquitin residues to the native MyoD. Ubiquitination of MyoD has been reported in several types of aging skeletal muscle [84] [85], and while the exact function of this process is unclear, the presence of ubiquitin may influence either the transcriptional activation and/or degradation of MyoD in aged muscle.

\section{Conclusion}

In conclusion, the results of this study indicate that a single session of manual acupuncture-induced injury to TA (ST36) muscle is sufficient to stimulate cellular and molecular events associated with the myogenic process in skeletal muscle of the aging rat in a manner similar to that seen in younger animals. The novel species of MyoD that are expressed in pre-senile female rats may in part compensate for physiologic changes that occur in aging satellite cells and their niché environment. Understanding the regenerative process that occurs following acupuncture in skeletal muscle of young and old animals may provide important clues about the localized response that underlies the efficacy of this procedure throughout the lifespan.

\section{Acknowledgements}

We wish to thank Dr. Kamal Ameis for his expertise and assistance in performing the acupuncture manipula- 
tions, Andrea R. Allen for her technical assistance.

\section{Research Support}

Funded in part by NIH grant S06 GM 08016-33 to SKS, and the Howard University Medical Alumni Association Endowed Founders Chair in the Basic Sciences to EW.

\section{References}

[1] Mauro, A. (1961) Satellite Cell of Skeletal Muscle Fibers. Journal of Biophysical and Biochemical Cytology, 9, 493-498. http://dx.doi.org/10.1083/jcb.9.2.493

[2] Schultz, E. and McCormick, K.M. (1994) Skeletal Muscle Satellite Cells. Reviews of Physiology, Biochemistry, and Pharmacology, 123, 213-257. http://dx.doi.org/10.1007/BFb0030904

[3] Grounds, M.D. (1999) Muscle Regeneration: Molecular Aspects and Therapeutic Implications. Current Opinion in Neurology, 12, 535-543. http://dx.doi.org/10.1097/00019052-199910000-00007

[4] Schultz, E., Jaryszak, D. and Valliere, C.R. (1985) Response of Satellite Cells in Focal Skeletal Muscle Injury. Muscle and Nerve, 8, 217-222. http://dx.doi.org/10.1002/mus.880080307

[5] Seale, P., Asakura, A. and Rudnicki, M.A. (2001) The Potential of Muscle Stem Cells. Developmental Cell, 1, $333-342$. http://dx.doi.org/10.1016/S1534-5807(01)00049-1

[6] Chargè, S.B. and Rudnicki, M.A. (2004) Cellular and Molecular Regulation of Muscle Regeneration. Physiological Reviews, 84, 209-238. http://dx.doi.org/10.1152/physrev.00019.2003

[7] Cooper, R.N., Tajbakhsh, S., Mouly, V., Cossu, G., Buckingham, M. and Butler-Browne, G.S. (1999) In Vivo Satellite Cell Activation via Myf5 and MyoD in Regenerating Mouse Skeletal Muscle. Journal of Cell Science, 112, $2895-2890$.

[8] D’Albis, A., Couteaux, R., Janmot, C., Roulet, A. and Mira, J.C. (1988) Regeneration after Cardiotoxin Injury of Innervated and Denervated Slow and Fast Muscles of Mammals: Myosin Isoform Analysis. European Journal of Biochemistry, 174, 103-110. http://dx.doi.org/10.1111/j.1432-1033.1988.tb14068.x

[9] Fink, E., Fortin, D., Serrurier, B., Ventura-Clapier, R. and Bigard, A.X. (2003) Recovery of Contractile and Metabolic Phenotypes in Regenerating Slow Muscle after Notexin-Induced or Crush Injury. Journal of Muscle Research and Cell Motility, 24, 421-429. http://dx.doi.org/10.1023/A:1027387501614

[10] Neto, H.S. and Marques, M.J. (2005) Microvessel Damage by B. Jararacussu Snake Venom: Pathogenesis and Influence on Muscle Regeneration. Toxicon, 46, 814-819. http://dx.doi.org/10.1016/j.toxicon.2005.08.013

[11] Singh, M.A., Ding, W., Manfredi, T.J., Solares, G.S., O’Neill, E.F., Clements, K.M., Ryan, N.D., Kehayias, J.J., Fielding, R.A. and Evans, W.J. (1999) Insulin-Like Growth Factor I in Skeletal Muscle after Weight-Lifting Exercise in Frail Elders. American Journal of Physiology, 277, E135-E143.

[12] Smith, H.K., Maxwell, L., Rodgers, C.D., McKee, N.H. and Plyley, M.J. (2001) Exercise-Enhanced Satellite Cell Proliferation and New Myonuclear Accretion in Rat Skeletal Muscle. Journal of Applied Physiology, 90, 1407-1414.

[13] Urtizberea, J.A., Fan, Q.S., Vroom, E., Recan, D. and Kaplan, J.C. (2003) Looking under Every Rock: Duchenne Muscular Dystrophy and Traditional Chinese Medicine. Neuromuscular Disorders, 13, 705-707. http://dx.doi.org/10.1016/S0960-8966(03)00116-0

[14] LeBlanc, K.E. and LeBlanc, L.L. (2010) Musculoskeletal Disorders. Primary Care, 37, 389-406. http://dx.doi.org/10.1016/j.pop.2010.02.006

[15] Amezaga, U.M. and Suarez-Almazor, M.E. (2012) Acupuncture in the Treatment of Rheumatic Disease. Current Rheumatology Reports, 14, 589-597. http://dx.doi.org/10.1007/s11926-012-0295-x

[16] Stux, G. (1998) Acupuncture Treatment. In: Pomeranz, B. and Stux, G., Eds., Basic Acupuncture, Springer-Verlag, Berlin, 214-271. http://dx.doi.org/10.1007/978-3-642-51433-3_6

[17] MacPherson, H. and Asghar, A. (2006) Acupuncture Needle Sensations Associated with De Qi: A Classification Based on Experts’ Ratings. Journal of Alternative and Complementary Medicine, 12, 633-637. http://dx.doi.org/10.1089/acm.2006.12.633

[18] Mao, J.J. and Kapur, R. (2010) Acupuncture in Primary Care. Primary Care, 37, 105-117. http://dx.doi.org/10.1016/j.pop.2009.09.010

[19] Ameis, K.M., Kanaan, Y.M., Das, J.R., George, M. and Sobrian, S.K. (2008) Effect of Manual Acupuncture-Induced Injury on Rat Skeletal Muscle. Medical Acupuncture, 20, 225-230. http://dx.doi.org/10.1089/acu.2008.0641

[20] Yablonke-Reveni, Z. (2011) The Skeletal Muscle Satellite Cell: Still Young and Fascinating at 50. Journal of Histochemistry and Cytochemistry, 59, 1041-1059. http://dx.doi.org/10.1369/0022155411426780 
[21] Carlson, B.M. and Faulkner, J.A. (1989) Muscle Transplantation between Young and Old Rats: Age of Host Determines Recovery. American Journal of Physiology, 256, C1262-C1266.

[22] Conboy, I.M., Conboy, M.J., Smythe, G.M. and Rando, T.A. (2003) Notch-Mediated Restoration of Regenerative Potential to Aged Muscle. Science, 302, 1575-1577. http://dx.doi.org/10.1126/science.1087573

[23] Rader, E.P. and Faulkner, J.A. (2006) Recovery from Contraction-Induced Injury Is Impaired in Weight-Bearing Muscles of Old Male Mice. Journal of Applied Physiology, 100, 656-661. http://dx.doi.org/10.1152/japplphysiol.00663.2005

[24] Conboy, I.M. and Rando, T.A. (2005) Aging, Stem Cells and Tissue Regeneration: Lessons from Muscle. Cell Cycle, 4, 407-410. http://dx.doi.org/10.4161/cc.4.3.1518

[25] Dedkov, E.I., Borisov, A.B., Wernig, A. and Carlson, B.M. (2003) Aging of Skeletal Muscle Does Not Affect the Response of Satellite Cells to Denervation. Journal of Histochemistry and Cytochemistry, 51, 853-863. http://dx.doi.org/10.1177/002215540305100701

[26] Liu, L. and Rando, T.A. (2011) Manifestations and Mechanisms of Stem Cell Aging. Journal of Cell Biology, 193, 257266. http://dx.doi.org/10.1083/jcb.201010131

[27] Biressi, S. and Rando, T.A. (2010) Heterogeneity in the Muscle Satellite Cell Population. Seminars in Cell and Developmental Biology, 21, 845-854. http://dx.doi.org/10.1016/j.semcdb.2010.09.003

[28] Gibson, M.C. and Schultz, E. (1983) Age-Related Differences in Absolute Numbers of Skeletal Muscle Satellite Cells. Muscle and Nerve, 6, 574-580. http://dx.doi.org/10.1002/mus.880060807

[29] Renault, V., Thornell, L.E., Eriksson, P.O., Butler-Browne, G. and Mouly, V. (2002) Regenerative Potential of Human Skeletal Muscle during Aging. Aging Cell, 1, 132-139. http://dx.doi.org/10.1046/j.1474-9728.2002.00017.x

[30] Shefer, G., Rauner, G., Yablonka-Reuveni, Z. and Benayahu, D. (2010) Reduced Satellite Cell Numbers and Myogenic Capacity in Aging Can Be Alleviated by Endurance Exercise. PLoS ONE, 5, Article ID: e13307. http://dx.doi.org/10.1371/journal.pone.0013307

[31] Snow, M.H. (1977) The Effects of Aging on Satellite Cells in Skeletal Muscle of Mice and Rats. Cell and Tissue Research, 185, 399-408. http://dx.doi.org/10.1007/BF00220299

[32] Tajbakhsh, S., Rocancourt, D., Cossu, G. and Buckingham, M. (1997) Redefining the Genetic Hierarchies Controlling Skeletal Myogenesis: Pax-3 and Myf-5 Act Upstream of MyoD. Cell, 89, 127-138. http://dx.doi.org/10.1016/S0092-8674(00)80189-0

[33] Kadi, F., Charifi, N., Christian, D. and Lexell, J. (2004) Satellite Cells and Myonuclei in Young and Elderly Women and Men. Muscle and Nerve, 29, 120-127. http://dx.doi.org/10.1002/mus.10510

[34] Shefer, G., Van de Mark, D.P., Richardson, J.B. and Yablonka-Reuveni, Z. (2006) Satellite-Cell Pool Size Does Matter: Defining the Myogenic Potency of Aging Skeletal Muscle. Developmental Biology, 294, 50-66. http://dx.doi.org/10.1016/j.ydbio.2006.02.022

[35] Hikida, R.S., Walsh, S., Barylski, N., Campos, G., Hagerman, F.C. and Staron, R.S. (1998) Is Hypertrophy Limited to Elderly Muscle Fibers? A Comparison of Elderly and Young Strength-Trained Men. Basic and Applied Myology, 8, 419-427.

[36] Roth, S.M., Martel, G.F., Ivey, F.M., Leemer, J.T., Metter, E.J., Hurley, B.F. and Rogers, M.A. (2000) Skeletal Muscle Satellite Cell Population in Healthy Young and Older Men and Women. Anatomical Record, 260, 351-358. http://dx.doi.org/10.1002/1097-0185(200012)260:4<350::AID-AR30>3.0.CO;2-6

[37] Roth, S.M., Martel, G.F., Ivey, F.M., Lemmer, J.T., Tracy, B.L., Metter, E.J., Hurley, B.F. and Rogers, M.A. (2001) Skeletal Muscle Satellite Cell Characteristics in Young and Older Men and Women after Heavy Resistance Strength Training. Journals of Gerontology, Series A: Biological Sciences and Medical Sciences, 56, B240-B247. http://dx.doi.org/10.1093/gerona/56.6.B240

[38] Wagers, A.J. and Conboy, I.M. (2005) Cellular and Molecular Signatures of Muscle Regeneration: Current Concepts and Controversies in Adult Myogenesis. Cell, 122, 659-667. http://dx.doi.org/10.1016/j.cell.2005.08.021

[39] Brack, A.S., Conboy, M.J., Roy, S., Lee, M., Kuo, C.J., Keller, C. and Rando, T.A. (2007) Increased Wnt Signaling during Aging Alters Muscle Stem Cell Fate and Increases Fibrosis. Science, 317, 807-810. http://dx.doi.org/10.1126/science.1144090

[40] Dedkov, E.I., Borisov, A.B. and Carlson, B.M. (2003) Dynamics of Postdenervation Atrophy of Young and Old Skeletal Muscles: Differential Responses of Fiber Types and Muscle Types. Journals of Gerontology, Series A: Biological Sciences and Medical Sciences, 58, B984-B991. http://dx.doi.org/10.1093/gerona/58.11.B984

[41] Hikida, R.S. (2011) Aging Changes in Satellite Cells and Their Functions. Current Aging Science, 4, $279-297$. http://dx.doi.org/10.2174/1874609811104030279

[42] Pannérec, A., Marazzi, G. and Sassoon, D. (2012) Stem Cells in the Hood: The Skeletal Muscle Niche. Trends in Mole- 
cular Medicine, 18, 599-606. http://dx.doi.org/10.1016/j.molmed.2012.07.004

[43] Carlson, B.M. and Faulkner, J.A. (1998) Muscle Regeneration in Young and Old Rats: Effects of Motor Nerve Transection with and without Marcaine Treatment. Journals of Gerontology, Series A: Biological Sciences and Medical Sciences, 53, B52-B58. http://dx.doi.org/10.1093/gerona/53A.1.B52

[44] Brack, A.S. and Rando, T.A. (2007) Intrinsic Changes and Extrinsic Influences of Myogenic Stem Cell Function during Aging. Stem Cell Reviews, 3, 226-237. http://dx.doi.org/10.1007/s12015-007-9000-2

[45] Gopinath, S.D. and Rando, T.A. (2008) Stem Cell Review Series: Aging of the Skeletal Muscle Stem Cell Niche. Aging Cell, 7, 590-598. http://dx.doi.org/10.1111/j.1474-9726.2008.00399.x

[46] García-Prat, L., Sousa-Victor, P. and Muñoz-Cánoves, P. (2013) Functional Dysregulation of Stem Cells during Aging: A Focus on Skeletal Muscle Stem Cells. FEBS Journal, 280, 4051-4062. http://dx.doi.org/10.1111/febs.12221

[47] Zacks, S.I. and Sheff, M.F. (1982) Age-Related Impeded Regeneration of Mouse Minced Anterior Tibial Muscle. Muscle and Nerve, 5, 152-161. http://dx.doi.org/10.1002/mus.880050213

[48] Conboy, I.M., Conboy, M.J., Wagers, A.J., Girma, E.R., Weissman, I.L. and Rando, T.A. (2005) Rejuvenation of Aged Progenitor Cells by Exposure to a Young Systemic Environment. Nature, 433, 760-764. http://dx.doi.org/10.1038/nature03260

[49] Collins, C.A., Zammit, P.S., Ruiz, A.P., Morgan, J.E. and Partridge, T.A. (2007) A Population of Myogenic Stem Cells that Survives Skeletal Muscle Aging. Stem Cells, 25, 885-894. http://dx.doi.org/10.1634/stemcells.2006-0372

[50] Freeman, M.E. (1998) The Ovarian Cycle of the Rat. In: Knobil, E. and Neill, J., Eds., The Physiology of Reproduction, Raven Press, New York, 1894-1928.

[51] Sokol, R.Z., Okuda, H., Stanczyk, F.Z., Wolfe, G.W., Delaney, J.C. and Chapin, R.E. (1999) Normative Reproductive Indices for Male and Female Adult Sprague-Dawley Rats. Contraception, 59, 203-207. http://dx.doi.org/10.1016/S0010-7824(99)00017-7

[52] Merry, B.J. and Holehan, A.M. (1979) Onset of Puberty and Duration of Fertility in Rats Fed a Restricted Diet. Journal the Society for Reproduction and Fertility, 57, 253-259. http://dx.doi.org/10.1530/jrf.0.0570253

[53] Tiidus, P.M. (2005) Can Oestrogen Influence Skeletal Muscle Damage, Inflammation, and Repair? British Journal of Sports Medicine, 39, 251-253. http://dx.doi.org/10.1136/bjsm.2005.016881

[54] Tiidus, P.M., Deller, M. and Liu, X.L. (2005) Oestrogen Influence on Myogenic Satellite Cells Following Downhill Running in Male Rats: A Preliminary Study. Acta Physiolgica Scandinavica, 184, 67-72. http://dx.doi.org/10.1111/j.1365-201X.2005.01427.x

[55] Enns, D.L. and Tiidus, P.M. (2010) The Influence of Estrogen on Skeletal Muscle: Sex Matters. Sports Medicine, 40, 1458. http://dx.doi.org/10.2165/11319760-000000000-00000

[56] Allen, R.E., McAllister, P.K. and Masak, K.C. (1980) Myogenic Potential of Satellite Cells in Skeletal Muscle of Old Rats. A Brief Note. Mechanisms of Ageing and Development, 13, 105-109. http://dx.doi.org/10.1016/0047-6374(80)90053-6

[57] Luo, D., Liu, S., Xie, X.P. and Hou, X.H. (2008) Electroacpuncture at Acupoint ST-36 Promotes Contractility of Distal Colon via a Cholinergic Pathway in Conscious Rats. Digestive Diseases and Sciences, 53, 689-693. http://dx.doi.org/10.1007/s10620-007-9929-7

[58] Yim, Y.K., Lee, H., Hong, K.E., Kim, Y.I., Lee, B.R., Son, C.G. and Kim, J.E. (2007) Electro-Acupuncture at Acupoint ST36 Reduces Inflammation and Regulates Immune Activity in Collagen-Induced Arthritic Mice. Evidence Based Complementary and Alternative Medicine, 4, 51-57. http://dx.doi.org/10.1093/ecam/nel054

[59] National Institutes of Health. (1997) Acupuncture. NIH Consensus Statement, 15, 1-34.

[60] Li, X., Hirokawa, M., Inoue, Y., Sugano, N., Qian, S. and Iwai, T. (2007) Effects of Acupressure on Lower Limb Blood Flow for the Treatment of Peripheral Arterial Occlusive Diseases. Surgery Today, 37, 103-108. http://dx.doi.org/10.1007/s00595-006-3347-x

[61] Ameis, K.M. (1991) Analgesic Effect of Captopril and Electroacupunture Stimulation. Proceedings of 1st Guangzhou International Conference of Traditional Chinese Medicine, Gangzhou, 1991.

[62] Ruchin, I.N. and Burdeiny, A.P. (1987) Auriculo-Electropuncture in Rheumatoid Arthritis (a Double-Blind Study). Terapevticheskil Arkhiv, 59, 26-30.

[63] Walters, E., Buchheit, K. and Maruniak, J.A. (1992) Receptor Neuron Losses Result in Decreased Cytochrome P-450 Immunoreactivity in Associated Non-Neuronal Cells of Mouse Olfactory Mucosa. Journal of Neuroscience Research, 33, 103-111. http://dx.doi.org/10.1002/jnr.490330113

[64] Baker, B.A., Mercer, R.R., Geronilla, K.B., Kashon, M.L., Miller, G.R. and Cutlip, R.G. (2006) Stereological Analysis of Muscle Morphology Following Exposure to Repetitive Stretch-Shortening Cycles in a Rat Model. Applied Physiology, 
Nutrition, and Metabolism, 31, 167-179. http://dx.doi.org/10.1139/h05-009

[65] Bradford, M.M. (1976) A Rapid and Sensitive Method for the Quantitation of Microgram Quantities of Protein Utilizing the Principle of Protein-Dye Binding. Analytical Biochemistry, 72, 248-254. http://dx.doi.org/10.1016/0003-2697(76)90527-3

[66] Ameis, K., Jayam Trouth, A., Bond, V. and Kanaan, Y. (2011) Degeneration/Regeneration as a Mechanism Contributing to the Effect of Manual Acupuncture-Induced Injury on Rat Skeletal Muscle, Acupuncture. In: Saad, M., Ed., Concepts and Physiology, InTech.

http://www.intechopen.com/books/acupuncture-concepts-and-physiology/degeneration-regeneration-as-a-mechanism-c ontributing-to-the-effect-of-manual-acupuncture-induced-in http://dx.doi.org/10.5772/24801

[67] Rathbone, C.R., Wenke, J.C., Warren, G.L. and Armstrong, R.B. (2003) Importance of Satellite Cells in the Strength Recovery after Eccentric Contraction-Induced Muscle Injury. American Journal of Physiology, Regulatory, Integrative and Comparative Physiology, 285, R1490-R1495.

[68] Velders, M., Schleipen, B., Fritzemeier, K.H., Zierau, O. and Diel, P. (2012) Selective Estrogen Receptors- $\beta$ Activation Stimulates Skeletal Nuscle Growth and Regeneration. FASEB Journal, 26, 1909-1920. http://dx.doi.org/10.1096/fj.11-194779

[69] Barberi, L., Scicchitano, B.M., De Rossi, M., Bigot, A., Duguez, S., Wielgosik, A., Stewart, C., McPhee, J., Conte, M., Narici, M., Franceschi, C., Mouly, V., Butler-Browne, G. and Musarò, A. (2013) Age-Dependent Alteration in Muscle Regeneration: The Critical Role of Tissue Niche. Biogerontology, 14, 273-292. http://dx.doi.org/10.1007/s10522-013-9429-4

[70] Cousin, W., Ho, M.L., Desai, R., Tham, A., Chen, R.Y., Kung, S., Elabd, C. and Conboy, I.M. (2013) Regenerative Capacity of Old Muscle Stem Cells Declines without Significant Accumulation of DNA Damage. PLoS ONE, 8, Article ID: e63528. http://dx.doi.org/10.1371/journal.pone.0063528

[71] Robertson, T.A., Maley, M.A., Grounds, M.D. and Papadimitriou, J.M. (1993) The Role of Macrophages in Skeletal Muscle Regeneration with Particular Reference to Chemotaxis. Experimental Cell Research, 207, 321-331. http://dx.doi.org/10.1006/excr.1993.1199

[72] Fisher, B.D., Baracos, V.E., Shnitka, T.K., Medbryk, S.W. and Reid, D.C. (1990) Ultrastructural Events Following Acute Muscle Trauma. Medicine and Science in Sports and Exercise, 22, 185-193.

[73] Roche, J.A., Lovering, R.M., Roche, R., Ru, L.W., Reed, P.W. and Bloch, R.J. (2010) Extensive Mononuclear Infiltration and Myogenesis Characterize Recovery of Dysferlin-Null Skeletal Muscle from Contraction-Induced Injuries. American Journal of Physiology, Cell Physiology, 298, C298-C312. http://dx.doi.org/10.1152/ajpcell.00122.2009

[74] Hawk, T.J. and Garry, D.J. (2001) Myogenic Satellite Cells: Physiology to Molecular Biology. Journal of Applied Physiology, 91, 534-551.

[75] Takaoka, Y., Ohta, M., Ito, A., Takamatsu, K., Sugano, A., Funakoshi, K., Takaoka, N., Sato, N., Yokosaki, H., Arizono, N., Goto, S. and Maeda, E. (2007) Electroacupuncture Suppresses Myostatin Gene Expression: Cell Proliferative Reaction in Mouse Skeletal Muscle. Physiological Genomics, 30, 102-110. http://dx.doi.org/10.1152/physiolgenomics.00057.2006

[76] Maga, G. and Hubscher, U. (2003) Proliferating Cell Nuclear Antigen (PCNA): A Dancer with Many Partners. Journal of Cell Science, 116, 3051-3060. http://dx.doi.org/10.1242/jcs.00653

[77] Buonanno, A., Cheng, J., Venepally, P., Weis, J. and Calvo, S. (1998) Activity-Dependent Regulation of Muscle Genes: Repressive and Stimulatory Effects of Innervation. Acta Physiologica Scandinavica, 163, S17-S26. http://dx.doi.org/10.1046/j.1365-201X.1998.1630s3S17.x

[78] Sabourin, L.A. and Rudnicki, M.A. (2000) The Molecular Regulation of Myogenesis. Clinical Genetics, 57, 16-25. http://dx.doi.org/10.1034/j.1399-0004.2000.570103.x

[79] Seale, P., Sabourin, L.A., Girgis-Gabardo, A., Mansouri, A., Gruss, P. and Rudnicki, M.A. (2000) Pax7 Is Required for the Specification of Myogenic Satellite Cells. Cell, 102, 777-786. http://dx.doi.org/10.1016/S0092-8674(00)00066-0

[80] Jones, S.W., Baker, D.J., Gardiner, S.M., Bennett, T., Timmons, J.A. and Greenhaff, P.L. (2004) The Effect of the $\beta_{2^{-}}$ Adrenoceptor Agonist Prodrug BRL-47672 on Cardiovascular Function, Skeletal Muscle Myosin Heavy Chain, and MyoD Expression in the Rat. Journal of Pharmacology and Experimental Therapeutics, 311, 1225-1231. http://dx.doi.org/10.1124/jpet.104.071589

[81] Velders, M. and Diel, P. (2013) How Sex Hormones Promote Skeletal Muscle Regeneration. Sports Medicine, 43, 10891100. http://dx.doi.org/10.1007/s40279-013-0081-6

[82] Day, K., Shefer, G., Shearer, A. and Yablonka-Reuveni, Z. (2010) The Depletion of Skeletal Muscle Satellite Cells with Age Is Concomitant with Reduced Capacity of Single Progenitors to Produce Reserve Progeny. Developmental Biology, 340, 330-343. http://dx.doi.org/10.1016/j.ydbio.2010.01.006

[83] Clarkson, P.M. and Hubal, M.J. (2001) Are Women Less Susceptible to Exercise-Induced Muscle Damage? Current 
Opinion in Clinical Nutrition and Metabolic Care, 4, 527-531. http://dx.doi.org/10.1097/00075197-200111000-00011

[84] Dedkov, E.I., Kostominova, T.Y., Borisov, A.B. and Carlson, B.M. (2003) MyoD and Myogenin Protein Expression in Skeletal Muscles of Senile Rats. Cell and Tissue Research, 311, 401-416.

[85] Puri, P.L. and Sartorelli, V. (2000) Regulation of Muscle Regulatory Factors by DNA-Binding, Interacting Proteins, and Post-Transcriptional Modifications. Journal of Cellular Physiology, 185, 155-173.

http://dx.doi.org/10.1002/1097-4652(200011)185:2<155::AID-JCP1>3.0.CO;2-Z 